\title{
LEXICAL COMPARISON IN HAYU: A LEXICOSTATISTICAL ANALYSIS
}

\author{
Tara M Rai
}

This article presents the lexicostatistical analysis of Hayu language based on 210 wordlist. There appear different ranges of lexical and phonetic similarities across the five different survey points. Being based on the Mudhajor, the core area of Hayu, exhibits a significant degree of lexical similarity with other points, i.e. Aadmara, Kodre, Wadi and Balingkhola. Such similarity percentages clearly indicate that Hayu spoken in five different points are mutually intelligible to each other. The lexicostatistical data, therefore, show that there is not much lexical variations across the villages where Hayu is spoken.

Keywords: lexicostatistical, phonetic, global correspondence, $\mathrm{COG}$

\section{Introduction}

Hayu is a Kirati language of Western Himalyish subgroup of Tibeto-Burman group of Sino Tibetan language family. It is mainly spoken in the Ramechhap and Sindhuli districts of Janakpur zone of Nepal. However, they are scattered across the districts like Sarlahi, Jhapa, Morang, Ilam, Udayapur ${ }^{2}$ and Kathmandu valley. The Hayu language is one of the shifting languages in Nepal (Eppele et al. 2012: 39). The term 'Hayu' refers to the people as well as the language they speak. They call their language as wayu da:bu 'Hayu language'. Hayu [ISO 639-3 vay) is recognized as the distinct national language. It is also an indigenous nationality that belongs to endangered group (NFDIN 2002: 20, $\S$ $2 \mathrm{C}$ ). Also it is considered to be closer to the neighboring languages; especially Kirat Rai languages. There exist three language verities in the Hayu speaking area, namely Ramechhaap and Sindhuli (Eppele et al. 2012: 39). The latest National Census of Nepal gives the number of mother tongue speakers as 1520 (CBS 2012).

Hayu is classified on the Expanded Graded Intergenerational Disruption Scale (EGIDS) as (7) shifting. This level of language vitality status is defined as, 'the language is used for face-to-face communication within all generations, but it is losing users' (Lewis and Simons 2015). The Hayus are one of the aboriginal peoples of Nepal. The equivalent term they use is 'Wayu, Bayu, Vayu, Wayo. They call themselves as the descents of the Kirat; however, they are highly influenced by the Hindu culture.

After they were given the allowance by the government in the name of social security, the Hayu people are indifferent in their traditional occupation. In a conversation with a Hayu named Gyan Bahadur in Kodre, he said that they prefer to produce more children in that they get more money from the government on the basis of the number of members in a

\footnotetext{
${ }^{1}$ The data used in this article are collected during the survey of Hayu language in Ramechhap and Sindhuli district (Rai and Tamang 2017).

2 In course of the field work we found the Hayu people living in the westernmost part of the Udayapur district (Rai and Tamang 2017).
}

Gipan 4. 2019. 162-174. 
household three thousand rupees each. Some of them are in the recruitment either in India or Nepal. Most of them are found to have changed their surnames and switched to Rai. Some others are in Kahtmandu valley working in various fields as a labor.

\section{Research methodology}

The methodology comprises the collection of wordlists and tools used in the analysis of the wordlists. First, the standardized wordlist of 210 words were elicited in the five different points, namely, Wadi, Mudhajor, Balingkhola, Kodre and Aadmara from the mother tongue speakers (grown up in the their locality, representing different sex, age and literacy), compiled them with phonetic transcriptions and cross-checked from other speakers from the same site. Secondly, the words from the wordlists were entered to the WordSurv (Wimbish 1989), a tool primarily used to determine the genetic relationship of the languages or dialects (Appendix 1). Thirdly, the words entered in the WordSurv were exported as WordSurv $6 \mathrm{XML}$ file to Cog for the comparison of the words collected in the five different points in terms of the lexical and phonetic similarity.

Cog is a tool for comparing languages using lexicostatistics and comparative linguistics procedures. It can be used to automate much of the process of comparing wordlists from different language varieties. Table 1 shows the five different survey points of Hayu language.

Table 1: Survey points of Hayu

\begin{tabular}{|l|l|l|l|}
\hline & Locality & Municipality & District \\
\hline 1 & Wadi & Ramechhap Municipality & \multirow{2}{*}{ Ramechhap, Sindhuli } \\
\hline 2 & Mudhajor & Ramechhap Municipality & \\
\hline 3 & Balingkhola & Ramechhap Municipality & \\
\hline 4 & Kodre & Kamalamai Municipality & \\
\cline { 1 - 3 } 5 & Adhmara & Kamalamai Municipality & \\
\hline
\end{tabular}

\subsection{Evaluation criteria}

Around $60 \%$ has been generally taken as a cutoff point for the evaluation of lexical similarity (Regmi 2013: 63). However, the 60\% threshold may not always be a strict cutoff point. Using such a method, the speech varieties having a lexical similarity less than $60 \%$ are considered as different languages. However, languages (or dialects) with around $60 \%$ or greater lexical similarity should be tested for intelligibility using another tool referred to as Recorded Text Test (RTT). The attitudes and the perceptions of the speakers are also important factors. Table 2 presents the evaluation criteria of the lexical similarity percentages.

Table 2: Evaluation criteria of the lexical similarity

\begin{tabular}{|c|l|l|l|}
\hline 1. & Lexical similarity (\%) & Evaluation & Remarks \\
\hline 2. & $\begin{array}{l}\text { Less than } 60 \% \\
\text { similarity }\end{array}$ & evaluation & $\begin{array}{l}\text { May not always be a strict } \\
\text { cutoff point }\end{array}$ \\
\hline
\end{tabular}


164 / Lexical comparison...

\begin{tabular}{|c|l|l|l|}
\hline 3. & $\begin{array}{l}60 \% \text { or more } \\
\text { similarity }\end{array}$ & $\begin{array}{l}\text { Different languages or dialects of } \\
\text { the same language }\end{array}$ & $\begin{array}{l}\text { Intelligibility testing is } \\
\text { required by using RTT }\end{array}$ \\
\hline 4. & $\begin{array}{l}\text { Higher than } 85 \% \\
\text { similarity }\end{array}$ & $\begin{array}{l}\text { Speech varieties likely to be } \\
\text { related dialects }\end{array}$ & - \\
\hline 5. & $\begin{array}{l}\text { Higher than } 95 \% \\
\text { similarity }\end{array}$ & Same language & - \\
\hline
\end{tabular}

3. Lexical comparison

In this section, we compare and analyze the 210 wordlist using a computer software COG, a recently developed program for lexical and phonetic comparison between and among dialects and languages. Cog allows us to compare and analyze wordlists from different language varieties using an iterative approach. Using this program we can quickly make sense of the data and then refine the wordlists and more settings, improving the comparison results and the understanding of the varieties at each step. We, first, present the lexical similarity in percentage among the five different points in the Hayu speech community and show then phonetic similarities among the survey points.

\subsection{Lexical similarity}

Lexical similarity in this study refers to the items not strictly following the phonetic realization of lexicon. Hayu presents different arrays of lexical similarity percentages among the survey points.

Table 3 presents the lexical similarity in percentage among the survey points in the Hayu speech community in the Ramechhap and Sindhuli districts.

Table 3: Lexical similarity among the key points of Hayu

\begin{tabular}{|l|l|l|l|l|l|}
\hline & Balingkhola & \multicolumn{1}{|c|}{ Aadmara } & Konre & Wadi & Mudhajor \\
\hline Balingkhola & $100 \%$ & $84 \%$ & $82 \%$ & $84 \%$ & $83 \%$ \\
\hline Aadmara & $84 \%$ & $100 \%$ & $91 \%$ & $82 \%$ & $82 \%$ \\
\hline Kodre & $82 \%$ & $91 \%$ & $100 \%$ & $80 \%$ & $81 \%$ \\
\hline Wadi & $84 \%$ & $82 \%$ & $80 \%$ & $100 \%$ & $85 \%$ \\
\hline Mudhajor & $83 \%$ & $82 \%$ & $81 \%$ & $85 \%$ & $100 \%$ \\
\hline
\end{tabular}

Table 3 shows that Mudhajor, the core area of Hayu, exhibits a significant degree (ranging from $81 \%$ to $85 \%$ ) of lexical similarity with other points, i.e. Wadi, Balingkhola, Kodre and Aadmara. Of the 210 words, Mudhajor exhibits the highest similarity with Wadi and the least similarity with Kodre. Until intelligibility testing is carried out by using RTT, only with the help of the 210 wordlist comparison may not determine whether it is form of different language or a dialect. But the lexical comparison is necessarily taken as one of the components to identify whether it is a distinct language or a dialect. 


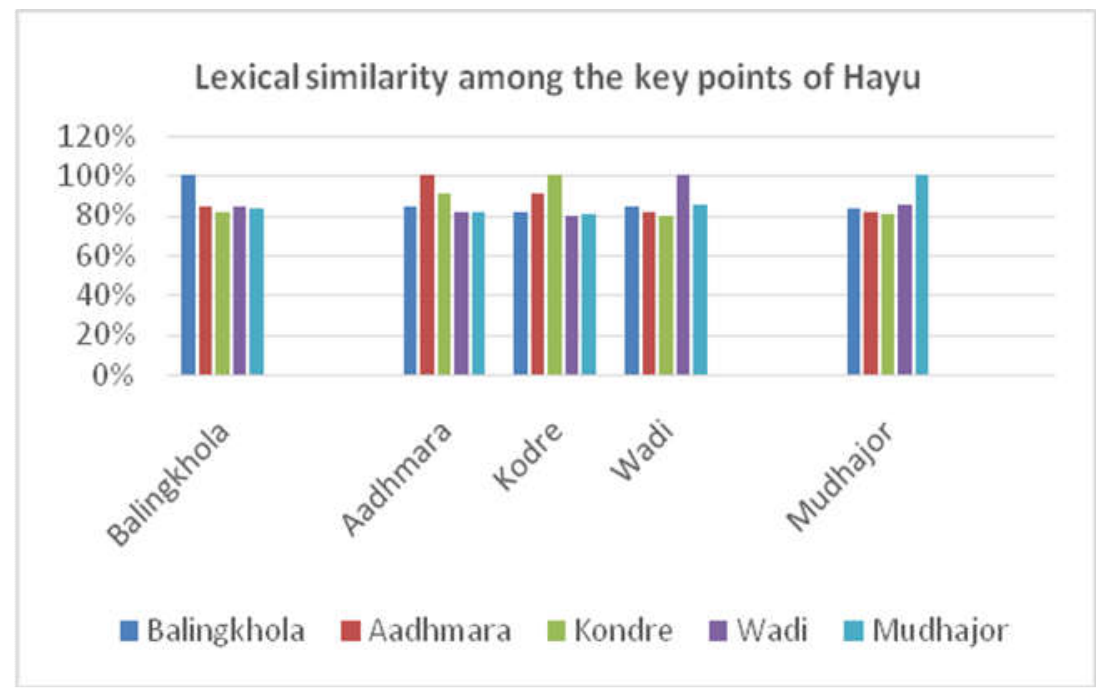

Figure 1: Lexical similarity among the key points of Hayu

Figure 1 presents the lexical similarities among the five different points in Hayu.

\subsection{Phonetic similarity}

Hayu presents different ranges of phonetic similarity percentages among the five different points. Unlike the lexical, phonetic similarity in this study means the phonetic realization of the lexicon compared each survey points: Balingkhola, Aadmara, Kodre, Wadi and Mudhajor.

Table 4 presents the phonetic similarity percentage among the five points in the Hayu speech community.

Table 4: Phonetic similarity in the five key points in the Hayu speech community (in percentage)

\begin{tabular}{|l|l|l|l|l|l|}
\hline & Balingkhola & Aadmara & Kodre & Wadi & Mudhajor \\
\hline Balingkhola & $100 \%$ & $86 \%$ & $85 \%$ & $85 \%$ & $85 \%$ \\
\hline Aadmara & $86 \%$ & $100 \%$ & $86 \%$ & $82 \%$ & $82 \%$ \\
\hline Kodre & $85 \%$ & $86 \%$ & $100 \%$ & $81 \%$ & $80 \%$ \\
\hline Wadi & $85 \%$ & $82 \%$ & $81 \%$ & $100 \%$ & $92 \%$ \\
\hline Mudhajor & $85 \%$ & $82 \%$ & $80 \%$ & $92 \%$ & $100 \%$ \\
\hline
\end{tabular}

Table 4 shows that as Mudhajor, the core area of Hayu exhibits a significant degree (ranging from $80 \%$ to $92 \%$ ) of phonetic similarity with other points, i.e. Aadmara, Kodre, Wadi, Balingkhola. To be precise, Mudhajor shares $85 \%$ with Balingkhola, $82 \%$ with Aadmara, 80\% with Kodre, and 92\% with Wadi. It shows that Mudhajor shares the highest phonetic similarity with Kodre and least with Wadi. 
166 / Lexical comparison...

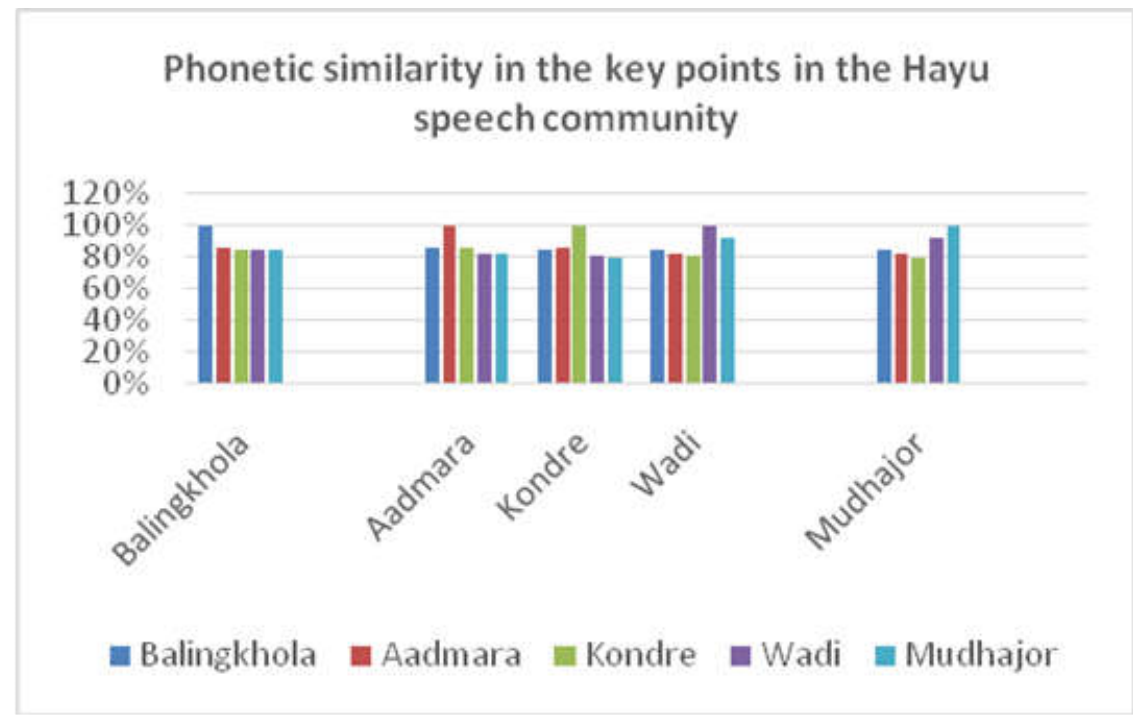

Figure 2: Phonetic similarity in the key points in the Hayu Speech community Figure 1 presents the phonetic similarities among the five different points in Hayu.

\section{Hierarchical graphs}

The lexicostatistical result of five different points in Hayu may be analyzed by hierarchical graph. Such graph displays the genetic relatedness of language verities based on lexicostatistical similarity.

There are two methods for mapping the graphs: UPGMA (Unweighted pair group method with arithmetic mean) and neighbor-joining. The UPGMA method is such a method that helps to construct the rooted tree base on a pairwise similarity matrix. In this method, at each step, the nearest two clusters are combined into a higher-level cluster. Dendogram 1 presents a hierarchical graph showing a rooted base tree.

Dendogram 1: Lexical similarity matrix

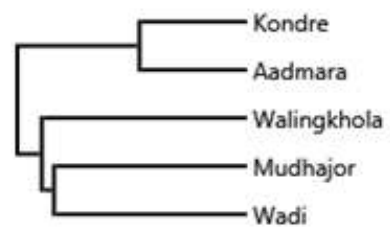

Lexical

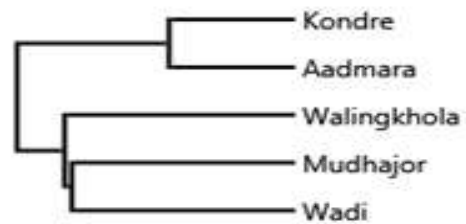

Phonetic

Dendogram 1 (a-b) shows that there basically two speech verities: a) Wadi b) Mudhajor c) Balingkhola in the one group whereas a) Kodre and b) Aadmara as another group. The points Wadi, Mudhajor and Balingkhola share the closer lexical and phonetic similarity. 
Similarly, the network graph lays out the language varieties, where similar varieties will tend to cluster together. This can be represented in the form of lexical and phonetic network graph in Dendogram 1 (a-b).

\section{Network relations}

The network relations show the relationship of the languages in two ways: first by showing the clusters of close languages and, secondly, by showing how they are nearer to each other.

In this network graph, all the verities within Hayu are compared to each other. The network graph shows that verities like Aadmara and Kodre seem to be closer than those of other verities. Similarly the verities like Mudhajor and Wadi tend to appear closer. On the other hand, Walingkhola is closer to the earlier group Aadmara and Kodre.

Figure 2 presents the similarity matrix network graph lexically and phonetically.

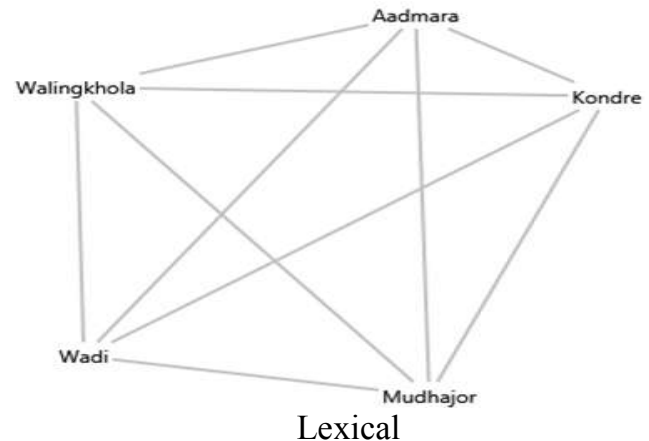

Lexical

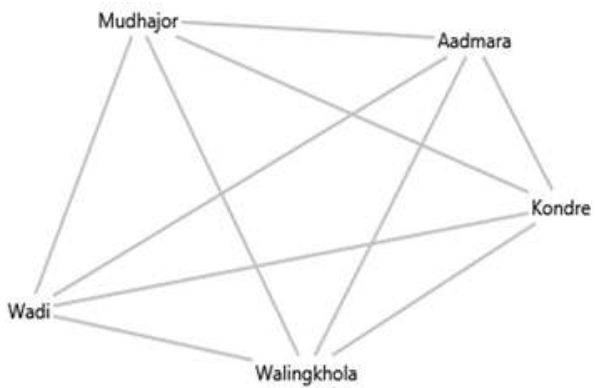

Phonetic

Figure 2: Lexical and phonetic similarity matrix network graph

In a Figure $2(a-b)$, the graph shows that the clusters of similar varieties and their connection. The speech community Wadi, Mudhajor and Balingkhola seem to be closer whereas the Speech community Kodre and Aadmara stand separately. This can be realized lexically. Unlike lexical network, the phonetic network seems to be a bit different since the point Mudhajor is up in the left corner and shows the close relation with Wadi and Walingkhola.

\section{Global correspondences}

The global correspondence displays all of the segments that occur in a particular syllable position across the wordlists from all the five different points. Edges indicate that at least one correspondence has occurred between those two segments. The thickness of the edge indicates the number of correspondences.

Figure 3 presents an IPA consonant chart (column headers are place of articulation; rows are manner of articulation) in their onset position. 
168 / Lexical comparison...

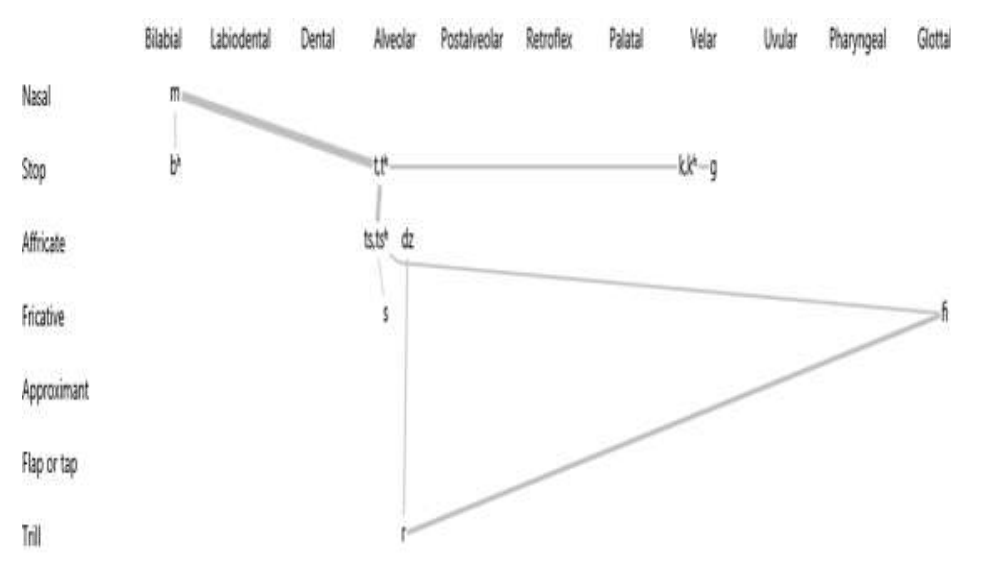

Lasalfinatio

Lated appoimat

Figure 3: Global correspondences of Hayu phonemes in onset position

Figure 3 allows us to get a good sense of correspondences that occur across multiple variety pairs in Hayu. The phoneme $/ \mathrm{m} /$ and $/ t / / t^{h /}$ indicate the thickness of the the segments share the most correspondence onset position. Also the thickness of the edges

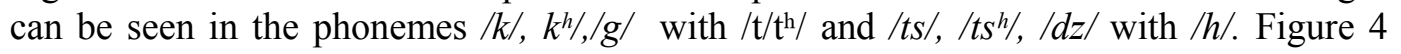
presents the corresponding of the different phonemes in their nucleus position.

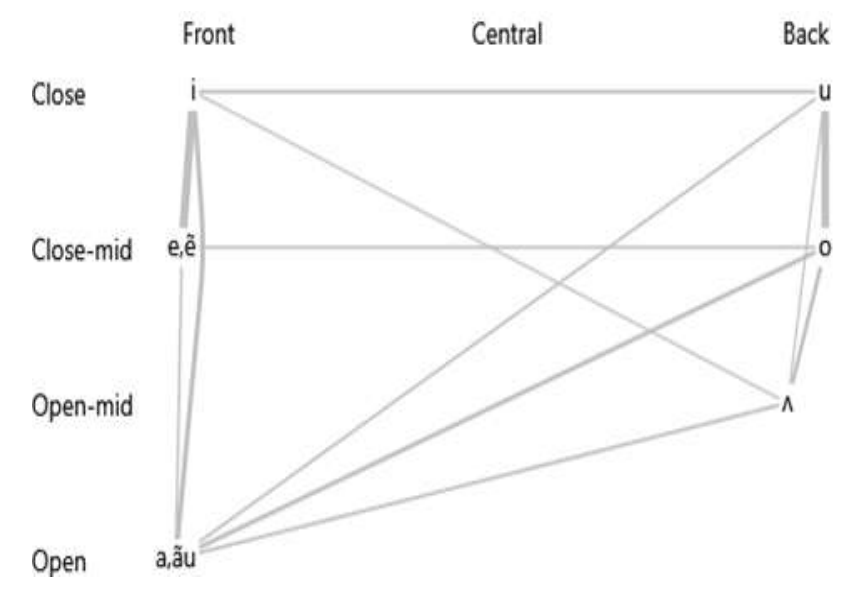

Figure 4: Global correspondence of Hayu phonemes in nucleus position

Figure 4 shows the vowels phonemes of Hayu in nucleus position of the syllables. The thickness of the edge indicates the number of correspondences. The frequency of vowels 
like close $/ \mathrm{i} /$, close-mid/e/,/ẽ/, open /a/,ã/ tend to appear as the nucleus position in the comparison to the wordlists. Also the back vowel $/ \mathrm{u} /, / \mathrm{O} /$ and $/ \Lambda /$ are realized as the nuclease position.

\section{Conclusion}

Hayu is one of the Kirati languages of Western Himalyish subgroup of Tibeto-Burman group of Sino Tibetan language family. While observing the ranges of lexical and phonetic similarities across the five different survey points being based on 210 wordlist, Mudhajor, the core area of Hayu, exhibits a significant degree of lexical similarity with other points, i.e. Aadmara, Kodre, Wadi and Balingkhola. Such similarity percentages clearly indicate that Hayu spoken in five different points are mutually intelligible to each other. Being based on the Mudhajor, the core area of Hayu, it exhibits a significant degree (ranging from $81 \%$ to $85 \%$ ) of lexical similarity with other points, i.e. Aadmara, Kodre, Wadi and Balingkhola. Of the 210 words, Mudhajor exhibits the highest similarity with Wadi and the least similarity with Kodre and Aadmara. The lexicostatistical data show that there is not much lexical variations among these five different points. Phonetically, Mudhajor, the core area of Hayu, exhibits a significant degree (ranging from $80 \%$ to $92 \%$ ) of phonetic similarity with other points, i.e. Aadmara, Kodre, Wadi and Balingkhola.

\section{References}

Bhusal, Sulochana. 2006. Nominal morphology in Hayu. Kathmandu: Tribhuvan University MA thesis.

Central Bureau of Statistics (CBS). 2012. National Population and Housing Census 2011 (National Report). Kathmandu: CBS.

Eppele, John W., M Paul Lewis, Dan Raj Regmi, Yogendra P. Yadava.2012. Ethnologue Languages of Nepal. Kathmandu: SIL international and Linguistic Survey of Nepal (LinSuN).

Hansson, Gerd. 1991. W. Winter (ed.). Linguistic Survey of Nepal: Ethnic and Linguistic Grouping. Findings of the Linguistic Survey of Nepal. Kathmandu: Centre for Nepal and Asian Studies, Tribhuvan University.

Lewis, M. P. and Simons, G. F. 2010. Assessing Endangerment: Expanding Fishman's GIDS. Revue Romaine de Linguistique 55. 103-120.

Michailovsky, Boyed. 1972. Notes on the Hay language. Kailash: A Journal of Himalayan Studies, 1(2). 135-152.

National Foundation for Development of Indigenous Nationalities (NFDIN). 2058BS. National Foundation for Development of Indigenous Nationalities Act. Kathmandu: Government of Nepal.

Rai, Tara Mani, Sizar Tamang. 2017. A Sociolinguistic Survey of Hayu: A Tibeto-Buramn Language. Kathmandu: Tribhuvan University Central Department of Linguistics Linguistic Survey of Nepal (LinSuN) Report.

Regmi, Ambika. 2013. A Sociolinguistic Survey of Magar Kaike: A Tibeto-Burman Language. Kathmandu: Tribhuvan University Central Department of Linguistics Linguistic Survey of Nepal (LinSuN) Report.

SIL International. 2014. Cog: A Tool for Comparing Languages Using Lexicostatistics and Comparative Linguistics Techniques. http://sillsdev.github.io/cog/ 
170 / Lexical comparison...

Wimbish, John S. 1989. WORDSURV: a program for analyzing language survey word lists.

Occasional Publications in Academic Computing 13. Dallas: Summer Institute of Linguistics

\section{Appendix}

Lexical items from five different points

\begin{tabular}{|c|c|c|c|c|c|c|}
\hline S.N. & English & Walingkhola & Kodre & Aadmara & Mudhajor & Wadi \\
\hline 1. & body & sırir & dziu & dziu & sırir & sırir \\
\hline 2. & head & pu?ts ${ }^{h} i$ & pu?ts ${ }^{h} i$ & puptshi & pu?ts ${ }^{h} i$ & pu?ts ${ }^{h} i$ \\
\hline 3. & hair & som & $s \wedge m$ & $s \wedge m$ & som & som \\
\hline 4. & face & muknts ${ }^{h} e u$ & gala & gala & mukatshe & mukatsheu \\
\hline 5. & eye & $m e k^{h}$ & $m e k^{h}$ & $m e k^{h}$ & $m e k^{h}$ & $m e k^{h}$ \\
\hline 6. & ear & noktsh ${ }^{h}$ & noktsh um & noktshum & nokts ${ }^{h} u$ & nokts ${ }^{h} u$ \\
\hline 7. & nose & $t s^{h}$ ?no & $t s^{h}$ ?no & $t s^{h}$ ?no & $t s^{h}$ ?no & $t s^{h}$ ?no \\
\hline 8. & mouth & muktsh ${ }^{h}$ & muktsh $u$ & muktsh $u$ & muktsh $u$ & muktsh $u$ \\
\hline 9. & teeth & $l u$ & $l u$ & $l u$ & $l u$ & $l u$ \\
\hline 10. & tongue & leya & liga & liga & liga & leya \\
\hline 11. & breast & $t s^{h} \tilde{a} t i$ & $t s^{h} \tilde{a} t i$ & $t s^{h} \tilde{a} t i$ & $t s^{h} \tilde{a} t i$ & $t s^{h} \tilde{a} t i$ \\
\hline 12. & belly & $b^{h} u ? d i$ & $b^{h} u ? d i$ & $b^{h} u ? d i$ & $b^{h} u ? d i$ & $b^{h} u ? d i$ \\
\hline 13. & arm/ hand & got & got & got & got & got \\
\hline 14. & elbow & kuina & kurkutsa & kurkutsa & kuina & kuina \\
\hline 15. & palm & hatkela & hatkela & hatkela & hatkela & hatkela \\
\hline 16. & finger & amla & ãula & ãula & amla & smla \\
\hline 17. & fingernail & dimen & dimen & dimen & dimen & dimen \\
\hline 18. & leg & le & le & le & le & le \\
\hline 19. & skin & kuktso & kuktso & kuktso & kuktso & kuktso \\
\hline 20. & bone & $r u$ & $r u$ & $r u$ & $r u$ & $r u$ \\
\hline 21. & heart & $t^{h} u m$ & $t^{\text {h } u m}$ & $t^{h} u m$ & $t^{h} u m$ & $t^{\text {h } u m}$ \\
\hline 22. & blood & hi & hi & hi & hi & hi \\
\hline 23. & urine & tsepi & tsepi & tsepi & tsepi & tsepi \\
\hline 24. & feces & $e^{2} p^{h} i$ & $e ? p^{h} i$ & $e_{i}^{2} p^{h} i$ & $e^{2} p^{h} i$ & $e^{2} p^{h} i$ \\
\hline 25. & village & $g \tilde{a} u$ & $g \tilde{a} u$ & $g \tilde{a} u$ & $g \tilde{a} u$ & $g \tilde{a} u$ \\
\hline 26. & house & kem & kem & kem & kem & kem \\
\hline 27. & roof & $t s^{h} a n a$ & $t s^{h} a n a$ & $t s^{h} a n a$ & $t s^{h} a n a$ & $t s^{h} a n a$ \\
\hline 28. & door & kamu & kamu & kamu & kamu & kamu \\
\hline 29. & firewood & $\sin$ & $\sin$ & $\sin$ & $\sin$ & $\sin$ \\
\hline 30. & broom & $b^{h}$ okim & $b^{h}$ okim & $b^{h}$ okim & $b^{h}$ okim & $b^{h}$ okim \\
\hline 31. & mortar & silouta & silouta & silouta & silouta & silouta \\
\hline 32. & pestle & lohora & lohora & lohora & lohora & lohora \\
\hline 33. & hammer & hımbır & $h \wedge m b \wedge r$ & $h \wedge m b \wedge r$ & $h \wedge m b \wedge r$ & hımbır \\
\hline 34. & knife & tsıkku & tsıkku & tsıkku & tsıkku & tsıkku \\
\hline 35. & axe & $k^{h}$ ojo & $k^{h}$ ojo & $k^{h}$ ojo & $k^{h}$ ojo & $k^{h}$ ojo \\
\hline 36. & rope & duri & duri & duri & duri & duri \\
\hline 37. & thread & $d^{h} a g o$ & $d^{h} a g o$ & $d^{h} a g o$ & $d^{h} a g o$ & $d^{h} a g o$ \\
\hline
\end{tabular}


Rai / 171

\begin{tabular}{|c|c|c|c|c|c|c|}
\hline 38. & needle & ts ${ }^{h} u t s u i$ & tsh utsui & tsh utsui & tsh utsui & tsh utsui \\
\hline 39. & cloth & dzewa & dzewa & dzewa & dzewa & dzewa \\
\hline 40. & ring & $\Delta m t^{h} i$ & $\Delta m t^{h} i$ & $\Delta m t^{h} i$ & $a m t^{h} i$ & $\Delta m t^{h} i$ \\
\hline 41. & sun & $n \wedge m \wedge$ & $n \wedge m \wedge$ & $n \wedge m \wedge$ & $n \wedge m \wedge$ & $n \wedge m \wedge$ \\
\hline 42. & moon & tsolo & tsolo & tsolo & tsolo & tsolo \\
\hline 43. & sky & akas & akas & akas & akas & akas \\
\hline 44. & star & tara & tara & tara & tara & tara \\
\hline 45. & rain & bırsa & barsa & bırsa & bırsa & bırsa \\
\hline 46. & water & $t i$ & $t i$ & $t i$ & $t i$ & $t i$ \\
\hline 47. & river & kosi & kosi & kosi & kosi & kosi \\
\hline 48. & cloud & kuiro & kuiro & kuiro & kuiro & kuiro \\
\hline 49. & lightening & tsımkainım & tsımkainım & tsımkainım & tsımkainım & tsımkainım \\
\hline 50. & rainbow & mutstsem & mutstsem & mutstsem & mutstsem & mutstsem \\
\hline 51. & wind & hudzuy & hudzuy & hudzuy & hudzuy & hudzuy \\
\hline 52. & stone & $l u ? p^{h}$ & $l u ? p^{h}$ & $l u ? p^{h}$ & $l u ? p^{h}$ & $l u ? p^{h}$ \\
\hline 53. & path & lom & lom & lom & lom & lom \\
\hline 54. & sand & baluwa & baluwa & baluwa & baluwa & baluwa \\
\hline 55. & fire & $m e ?$ & $m e ?$ & $m e ?$ & $m e ?$ & $m e ?$ \\
\hline 56. & smoke & kulu & kulu & kulu & kulu & kulu \\
\hline 57. & ash & dawaymi & dawaymi & dawaymi & dawaymi & dawaymi \\
\hline 58. & mud & ko? & ko? & ko? & ko? & ko? \\
\hline 59. & dust & $d^{h} u l o$ & $d^{h} u l o$ & $d^{h} u l o$ & $d^{h} u l o$ & $d^{h} u l o$ \\
\hline 60. & gold & sun & sun & sun & sun & sun \\
\hline 61. & tree & $p^{h} u m$ & $p^{h} u m$ & $p^{h} u m$ & $p^{h} u m$ & $p^{h} u m$ \\
\hline 62. & leaf & lo & lo & lo & lo & lo \\
\hline 63. & root & $d z \wedge r a$ & $d z \wedge r a$ & $d z \wedge r a$ & $d z \wedge r a$ & $d z \wedge r a$ \\
\hline 64. & thorn & $s u$ & $s u$ & $s u$ & $s u$ & su \\
\hline 65. & flower & $p u$ & $p u$ & $p u$ & $p u$ & $p u$ \\
\hline 66. & fruit & semi & semi & semi & semi & semi \\
\hline 67. & mango & $d z u l i$ & $d z u l i$ & $d z u l i$ & dzuli & $d z u l i$ \\
\hline 68. & banana & risa & risa & risa & risa & risa \\
\hline 69. & wheat(husked) & gıhu & gıhu & gıhu & gıhu & gıhu \\
\hline 70 . & barley & $d z o u$ & $d z o u$ & $d z o u$ & $d z o u$ & dzou \\
\hline 71. & rice (husked) & tshjayra & tshjayra & tshjayra & ts ${ }^{h j a \eta r a}$ & ts ${ }^{h j a \eta r a}$ \\
\hline 72. & potato & alu & alu & alu & alu & alu \\
\hline 73. & eggplant & $b^{h} e n t a$ & $b^{h}$ enta & $b^{h}$ enta & $b^{h} e n t a$ & $b^{h}$ enta \\
\hline 74. & groundnut & bıdam & bıdam & bıdam & bıdam & bıdam \\
\hline 75. & chili & sots ${ }^{h}$ eypoi & sotsheypoi & sots $^{h}$ eypoi & sots ${ }^{h}$ eypoi & sots $^{h}$ eypoi \\
\hline 76. & turmeric & hırdi & hardi & hardi & hırdi & hardi \\
\hline 77. & garlic & lasun & lasun & lasun & lasun & lasun \\
\hline 78. & onion & pyadz & pyadz & pyadz & pyadz & pyadz \\
\hline 79. & cauliflower & kauli & kauli & kauli & kauli & kauli \\
\hline 80 . & tomato & belouti & belouti & belouti & belouti & belouti \\
\hline 81. & cabbage & $b ? n d a$ & $b ? n d a$ & $b ? n d a$ & $b ? n d a$ & $b ? n d a$ \\
\hline 82. & oil & $k i$ & $k i$ & $k i$ & $k i$ & $k i$ \\
\hline
\end{tabular}


172 / Lexical comparison...

\begin{tabular}{|c|c|c|c|c|c|c|}
\hline 83. & salt & $t$ tsja & tsja & tsja & tsja & tsja \\
\hline 84. & meat & kun & kun & kun & kun & kun \\
\hline 85. & fat (of meat) & boso & boso & boso & boso & boso \\
\hline 86. & fish & mats $^{h} a$ & mats $^{h} a$ & mats ${ }^{h} a$ & mats $^{h} a$ & mats $^{h} a$ \\
\hline 87. & chicken & tsija? & tsija? & tsija? & tsija? & tsija? \\
\hline 88. & egg & tsalum & tsalum & tsalum & tsalum & tsalum \\
\hline 89. & cow & gai & gai & gai & gai & gai \\
\hline 90. & buffalo & $p^{\text {hitam }}$ & $p^{\text {hitam }}$ & $p^{\text {hitam }}$ & $p^{\text {hitam }}$ & $p^{\text {hitam }}$ \\
\hline 91. & milk & $d u d^{h}$ & $d u d^{h}$ & $d u d^{h}$ & $d u d^{h}$ & $d u d^{h}$ \\
\hline 92. & horns & ruy & ruy & ruy & ruy & rum \\
\hline 93. & tail & mun & mun & mun & mun & mun \\
\hline 94. & goat & tseli & tseli & tseli & tseli & tseli \\
\hline 95. & $\operatorname{dog}$ & uri & uri & uri & uri & uri \\
\hline 96. & snake & hobu & hobu & hobu & hobu & hobu \\
\hline 97. & monkey & rints ${ }^{h} e u$ & rints $^{h} e u$ & rints ${ }^{h} e u$ & rints ${ }^{h} e u$ & rints ${ }^{h} e u$ \\
\hline 98. & mosquito & lamkue & lamkue & lamkue & lamkue & lamkue \\
\hline 99. & ant & tsikibu?la & tsikibu?la & tsikibu?la & tsikibu?la & tsikibu?la \\
\hline 100. & spider & makura & makura & makura & makura & makura \\
\hline 101. & name & nam & nam & nam & nam & nam \\
\hline 102. & $\operatorname{man}$ & sintoy & sintoy & sintoy & sintoy & sintoy \\
\hline 103. & woman & mistso & mistso & mistso & mistso & mistso \\
\hline 104. & child & tsola & tsola & tsola & tsola & tsola \\
\hline 105. & father & u?po & u?po & u?po & и?ро & u?po \\
\hline 106. & mother & u?mo & u? & uशmo & u?mo & u?mo \\
\hline 107. & older brother & bulu & bulu & bulu & bulu & bulu \\
\hline 108. & $\begin{array}{l}\text { younger } \\
\text { brother }\end{array}$ & balu & balu & balu & balu & balu \\
\hline 109. & older sister & nono & nono & nono & nono & nono \\
\hline 110. & younger sister & diu & diu & diu & diu & diu \\
\hline 111. & son & tao & tao & tao & tao & tao \\
\hline 112. & daughter & tami & tami & tami & tami & tami \\
\hline 113. & husband & rostso & rostso & rostso & rostso & rostso \\
\hline 114. & wife & ro?mi & ro?mi & ro?mi & ro?mi & ro?mi \\
\hline 115. & boy & to & to & to & to & to \\
\hline 116. & girl & tame & tame & tame & tame & tame \\
\hline 117. & day & $\operatorname{din}$ & $\operatorname{din}$ & $\operatorname{din}$ & $\operatorname{din}$ & $\operatorname{din}$ \\
\hline 118. & night & jeksa & jeksa & jeksa & jeksa & jeksa \\
\hline 119. & morning & nuто & numo & nuто & nuто & nuто \\
\hline 120. & noon & nu?me & nu?me & nu?me & nu?me & nu?me \\
\hline 121. & evening & jeksadumi & jeksadumi & jeksadumi & jeksadumi & jeksadumi \\
\hline 122. & yesterday & listson & listson & listson & listson & listson \\
\hline 123. & today & tiri & tiri & tiri & tiri & tiri \\
\hline 124. & tomorrow & nukon & nukon & nukon & nukon & nukon \\
\hline 125. & week & sata & sata & sata & sata & sata \\
\hline 126. & month & maina & maina & mıina & mıina & maina \\
\hline
\end{tabular}


Rai / 173

\begin{tabular}{|c|c|c|c|c|c|c|}
\hline 127. & year & bırss & bırsı & bırsı & barsa & bırss \\
\hline 128. & old & purano & purano & purano & purano & purano \\
\hline 129. & new & nesem & nesem & nesem & nesem & nesem \\
\hline 130. & good & dimtsome & dimtsome & dimtsome & dimtsome & dimtsome \\
\hline 131. & bad & madimtsom & madimtsom & madimtsom & madimtsom & madimtsom \\
\hline 132. & wet & natsoy & natsoy & natsoy & natsoy & natsoy \\
\hline 133. & dry & $\operatorname{sukk}^{h} a$ & $s u k k^{h} a$ & $\operatorname{sukk}^{h} a$ & $\operatorname{sukk}^{h} a$ & $\operatorname{sukk}^{h} a$ \\
\hline 134. & long & $p^{h i t a}$ & $p^{h}$ ita & $p^{h}$ ita & $p^{h}$ ita & $p^{h}$ ita \\
\hline 135. & short & $i t^{h} a p i$ & $i t^{h} a p i$ & $i t^{h} a p i$ & $i t^{h} a p i$ & $i t^{h} a p i$ \\
\hline 136. & hot & tato & tato & tato & tato & tato \\
\hline 137. & cold & $d z u s a$ & dzusa & dzusa & dzusa & dzusa \\
\hline 138. & right & daine & daine & daine & daine & daine \\
\hline 139. & left & debre & debre & debre & debre & debre \\
\hline 140. & near & $k^{h} e w a$ & $k^{h} e w a$ & $k^{h} e w a$ & $k^{h} e w a$ & $k^{h} e w a$ \\
\hline 141. & far & $k^{h}$ o?lam & $k^{h}$ o?lam & $k^{h}$ o?lam & $k^{h}$ oPlam & $k^{h}$ o?lam \\
\hline 142. & big & $k^{h} \tilde{o t a}$ & $k^{h} \tilde{o} t a$ & $k^{h} \tilde{o t a}$ & $k^{h} \tilde{o t a}$ & $k^{h} \tilde{o} t a$ \\
\hline 143. & small & $d^{h} u m t i$ & $d^{h} u m t i$ & $d^{h} u m t i$ & $d^{h} u m t i$ & $d^{h} u m t i$ \\
\hline 144. & heavy & lista & lista & lista & lista & lista \\
\hline 145. & light & oksa & oksa & oksa & oksa & oksa \\
\hline 146. & above & one & one & one & one & one \\
\hline 147. & below & hute & hute & hute & hute & hute \\
\hline 148. & white & duwaymi & duwaymi & duwaymi & duwaymi & duwaymi \\
\hline 149. & black & $k^{h}$ aktseymi & $k^{h}$ aktseymi & $k^{h}$ aktseymi & $k^{h}$ aktseymi & $k^{h}$ aktseymi \\
\hline 150. & red & hitshigmi & hitshigmi & hitshigmi & hitshigmi & hitshigmi \\
\hline 151. & one & kolu & kolu & kolu & kolu & kolu \\
\hline 152. & two & nakuy & nakuy & nakuy & nakuy & nakuy \\
\hline 153. & three & sim & $\operatorname{sim}$ & $\operatorname{sim}$ & $\operatorname{sim}$ & $\operatorname{sim}$ \\
\hline 154. & four & - & - & - & - & - \\
\hline 155. & five & - & - & - & - & - \\
\hline 156. & six & - & - & - & - & - \\
\hline 157. & seven & - & - & - & - & - \\
\hline 158. & eight & - & - & - & - & - \\
\hline 159. & nine & - & - & - & - & - \\
\hline 160. & ten & - & - & - & - & - \\
\hline 161. & eleven & - & - & - & - & - \\
\hline 162. & twelve & - & - & - & - & - \\
\hline 163. & twenty & - & - & - & - & - \\
\hline 164. & one hundred & - & - & - & - & - \\
\hline 165. & who & suno & suno & suno & suno & suno \\
\hline 166. & what & mitsi & mitsi & mitsi & mitsi & mitsi \\
\hline 167. & where & hani & hani & hani & hani & hani \\
\hline 168. & when & $h a k^{h} i$ & $h a k^{h} i$ & $h a k^{h} i$ & $h a k^{h} i$ & $h a k^{h} i$ \\
\hline 169. & how many & haat $^{h} a$ & haat $^{h} a$ & haat $^{h} a$ & haat $^{h} a$ & haat $^{\text {ha }}$ \\
\hline 170. & which & hanam & hanam & hanam & hanam & hanam \\
\hline 171. & this & $i$ & $i$ & $i$ & $i$ & $i$ \\
\hline
\end{tabular}


174 / Lexical comparison...

\begin{tabular}{|c|c|c|c|c|c|c|}
\hline 172. & that & $m i ?$ & $m i ?$ & $m i ?$ & $m i ?$ & $m i ?$ \\
\hline 173. & these & $i k^{h} a t a$ & $i k^{h} a t a$ & $i k^{h} a t a$ & $i k^{h} a t a$ & $i k^{h} a t a$ \\
\hline 174. & those & $m i k^{h} a t a$ & $m i k^{h} a t a$ & mik ${ }^{h} a t a$ & mik $^{h} a t a$ & mik $a t a$ \\
\hline 175. & same & $m i ?$ & $m i ?$ & $m i ?$ & $m i ?$ & $m i ?$ \\
\hline 176. & different & $t s^{h}$ alim & $t s^{h}$ alim & $t s^{h}$ alim & $t s^{h}$ alim & $t s^{h}$ alim \\
\hline 177. & whole & ko?namuti & ko?namuti & ko?namuti & ko?namuti & ko?namuti \\
\hline 178. & broken & re?lekat?m & rePlekat?m & re?lekat?m & rePlekat?m & rePlekat? $m$ \\
\hline 179. & few & denineretso & denineretso & denineretso & denineretso & denineretso \\
\hline 180. & many & sunnaretso & sunnaretso & sunnaretso & sunnaretso & sunnaretso \\
\hline 181. & all & $d z a k^{h} m$ & $d z a k^{h} m$ & $d z a k^{h} m$ & $d z a k^{h} m$ & $d z a k^{h} m$ \\
\hline 182. & to eat & dzama & dzama & dzama & dzama & dzama \\
\hline 183. & to bite & $k^{h}$ awapma & $k^{h}$ awapma & $k^{h}$ awapma & $k^{h}$ awapma & $k^{h}$ awapma \\
\hline 184. & to be hungry & sukma & sukma & sukma & sukma & sukma \\
\hline 185. & to drink & $t u^{h} m a$ & $t u^{h} m a$ & $t u^{h} m a$ & $t u^{h} m a$ & $t u^{h} m a$ \\
\hline 186. & to be thirsty & tidukma & tidukma & tidukma & tidukma & tidukma \\
\hline 187. & to sleep & imma & imma & imma & imma & imma \\
\hline 188. & to lie & pultema & pultema & pultema & pultema & pultema \\
\hline 189. & to sit & $m u ? m a$ & mu?ma & mu?ma & $m u ? m a$ & mu?ma \\
\hline 190. & to give & haama & haama & haama & haama & haama \\
\hline 191. & to burn & himma & himma & himma & himma & himma \\
\hline 192. & to die & mertema & me?tema & mertema & mertema & mertema \\
\hline 193. & to kill & se?tma & se?tma & se?tma & se?tma & se?tma \\
\hline 194. & to fly & bınma & $b \wedge n m a$ & bınma & bınma & bınma \\
\hline 195. & to walk & $k^{h}$ okma & $k^{h}$ okma & $k^{h}$ okma & $k^{h}$ okma & $k^{h}$ okma \\
\hline 196. & to run & lonma & lonma & lonma & lonma & lonma \\
\hline 197. & to go & lakma & lakma & lakma & lakma & lakma \\
\hline 198. & to come & $p^{h i m a}$ & $p^{h i m a}$ & $p^{h} i m a$ & $p^{h} i m a$ & $p^{h} i m a$ \\
\hline 199. & to speak & gonma & gonma & gonma & gonma & gonma \\
\hline 200. & to hear/listen & $t^{h} a k m a$ & $t^{h} a k m a$ & $t^{h} a k m a$ & $t^{h} a k m a$ & $t^{h} a k m a$ \\
\hline 201. & to look & tsu?akma & tsu?akma & tsu?akma & tsu?akma & tsu?akma \\
\hline 202. & $\mathrm{I}$ & $a \eta$ & $a \eta$ & $a \eta$ & $a \eta$ & $a \eta$ \\
\hline 203. & you (informal) & $u \eta$ & $u \eta$ & $u \eta$ & $u \eta$ & $u \eta$ \\
\hline 204. & you (formal) & gon & gon & gon & gon & gon \\
\hline 205. & he & $m i ?$ & $m i ?$ & $m i ?$ & $m i ?$ & $m i ?$ \\
\hline 206. & she & $m i ?$ & $m i ?$ & $m i ?$ & $m i ?$ & $m i ?$ \\
\hline 207. & we (inclusive) & gonnuy & gonnuy & gonnuy & gonnuy & gonnuy \\
\hline 208. & we (exclusive) & $\tilde{a k i k} k^{h} a t a$ & $\tilde{a k i k} k^{h} a t a$ & $\tilde{a k i k} k^{h} a t a$ & $\tilde{a k i k^{h} a t a}$ & $\tilde{a k i k} k^{h} a t a$ \\
\hline 209. & you (plural) & gonek $^{h}$ ata & gonek $^{h}$ ata & gonek $^{h}$ ata & gonek $^{h}$ ata & gonek $^{h}$ ata \\
\hline 210. & they & $m i k^{h} a t a$ & $m i k^{h} a t a$ & $m i k^{h} a t a$ & mik $^{h} a t a$ & $m i k^{h} a t a$ \\
\hline
\end{tabular}

